\title{
Subclinical hypomagnesemia: Prevalence and causes in dairy cows in the semiarid region of the state of Paraíba, Brazil
}

\author{
Hipomagnesemia subclínica: Prevalência e causas em vacas leiteiras da região \\ semiárida no estado da Paraíba, Brasil
}

\author{
SILVA, Daniel Cézar da ${ }^{1 *}$ \\ https://orcid.org/0000-0002-2363-2890
}

FERNANDES, Beatriz Dantas ${ }^{2}$

https://orcid.org/0000-0001-7474-6962

LIMA, Jéssica Monique dos Santos ${ }^{3}$

https://orcid.org/0000-0001-9868-6896

\author{
SILVA, Bismark Alves da ${ }^{4}$ \\ https://orcid.org/0000-0003-4265-4742
}

RODRIGUES, Gilderlândio Pinheiro ${ }^{4}$ https://orcid.org/0000-0003-0845-099X

SOUZA, Evaristo Jorge Oliveira de https://orcid.org/0000-0002-2206-414X

${ }^{1}$ Federal Institute of Education, Science and Technology of Paraíba, Presidente Tancredo Neves Street, Sousa, ZIP Code: 58814000, Paraíba, Brazil;

${ }^{2}$ Postgraduate Program in Animal Science of the University Federal Rural of Semiarid, Francisco Mota Street, 572, Pres. Costa e Silva, Mossoró, ZIP Code: 59625-900, Rio Grande do Norte, Brazil;

${ }^{3}$ Medical Clinic and Surgery of Large Animals Residence of the University Federal Rural of Semiarid, Francisco Mota Street, 572, Pres. Costa e Silva, Mossoró, ZIP Code: 59625900, Rio Grande do Norte, Brazil;

${ }^{4}$ Independent Veterinary, Mossoró, Rio Grande do Norte, Brazil;

${ }^{5}$ University Federal Rural of Pernambuco, Serra Talhada Academic Unit, Gregório Ferraz Nogueira Street, ZIP Code: 56909535, Serra Talhada, Brazil.

*Corresponding author. Tel: +5583999371379; e-mail: daniel.cezar@ifpb.edu.br

\begin{abstract}
In dairy farming, cows display important metabolic changes during the transition period, particularly high-production cows, which need nutrients in greater quantity to meet the required demand. The aim of this study was to determine the prevalence of subclinical hypomagnesemia in pre- and post-partum dairy cows inserted in milk-production systems in the Sousa microregion and the district of São João do Rio do Peixe, both in the State of Paraíba, Brazil. As such, visits were made every two weeks to 34 rural properties, where the team collected 357 blood samples by venepuncture, 106 from pre-partum lactating cows and 251 from lactating cows in the post-partum period. It was found that the properties supplied three types of mineral supplement: a single supplement of $\mathrm{NaCl}$, a supplement of $\mathrm{NaCl}+$ mineral base, and a commercial supplement. The cows receiving the commercial mineral supplement had the highest prevalence $(10.53 \%)$ of the disorder, even showing a significant difference $(\mathrm{P}<.05)$ between the other types of supplement. In relation to reproductive period, it was found that the post-partum cows had a higher prevalence of subclinical hypomagnesemia (9.96\%) than did the pre-partem cows $(8.49 \%)$; there was, however, no significant difference $(\mathrm{P}>.05)$ between the two. Studies
\end{abstract}


such as this are fundamental for alerting rural and technical producers to the occurrence of subclinical hypomagnesemia in the region, in addition to the damage caused by metabolic disorders.

Keywords: cattle farming, magnesium, metabolic disorders, mineral supplement

\section{RESUMO}

$\mathrm{Na}$ bovinocultura leiteira, as vacas apresentam mudanças metabólicas importantes durante o período de transição, principalmente aquelas de alta produção, que necessitam de nutrientes em maior quantidade para suprir a demanda requerida. Este estudo teve como objetivo determinar a prevalência de hipomagnesemia subclínica no pré e pós-parto em vacas leiteiras inseridas em sistemas de produção de leite na microrregião de SousaPB e município de São João do Rio do Peixe-PB. Para isso foram realizadas visitas quinzenais a 34 propriedades rurais, onde a equipe coletou 357 amostras de sangue por meio de punção venosa, sendo 106 provenientes de vacas em lactação que se encontravam no período de pré-parto e 251 de vacas em lactação inseridas no período de pós-parto. Verificou-se que as propriedades forneciam três tipos de suplemento mineral: suplementação exclusiva com $\mathrm{NaCl}$; suplementação com $\mathrm{NaCl}+$ núcleo mineral; e suplementação comercial. As vacas que recebiam a suplementação mineral do tipo comercial corresponderam aquelas com maior prevalência $(10,53 \%)$ de ocorrência do distúrbio, apresentando ainda diferença significativa $(\mathrm{P}<0,05)$ entre as demais formas de suplementação. Em relação ao período reprodutivo em que as vacas se encontravam, notou- se que aquelas do pós-parto apresentaram maior prevalência de hipomagnesemia subclínica $(9,96 \%)$ em relação às vacas do pré-parto $(8,49 \%)$. Porém não houve diferença significative $(\mathrm{P}>0,05)$ entre ambas. Estudos como esse tornam-se fundamentais para alertar produtores rurais e técnicos sobre a ocorrência da hipomagnesemia subclínica na região, além dos prejuízos que os distúrbios metabólicos acarretam.

Palavras-chave: desordens metabólicas, magnésio, pecuária, suplementação mineral

\section{INTRODUCTION}

The transition period includes three weeks before and after delivery, and is considered a critical phase in milkproduction systems (Wang et al., 2012). Sudden changes in the metabolic and endocrine functions of the dairy cow that are associated with calving and early lactation make the transition period inherently difficult for the animal (Degaris \& Lean, 2009).

During this period diet is considered a conditioning element in the satisfactory performance, and when not given due attention, the animals may display reduced production (Sheehy et al., 2016). In nutritional management, mineral supply is essential for maintaining organic homeostasis, and during the preand post-partum period the cows can suffer changes in serum levels, with damage to the metabolism responsible for milk production.

Against this scenario, some minerals such as magnesium $(\mathrm{Mg})$ are reduced to below physiological levels, when dairy cows may present cases of clinical or subclinical hypomagnesemia, causing anorexia, hyperirritability, abnormal muscle contractions, excessive salivation, decreased rumen and 
abomasum motility and reduced immune response (Goff, 2014; Moreira et al., 2015), with compromised dairy production.

$\mathrm{Mg}$ is a cofactor of enzyme systems, as for example in the bone tissue and kidneys, modulating, respectively, the mobilization of bone $\mathrm{Ca}$ and renal production of 1,25-dihydroxyvitamin $\mathrm{D}$, to restore blood $\mathrm{Ca}$ concentration to normal levels (Martín-Tereso \& Martens, 2014), it is related to calcium (Ca) homeostasis in which $\mathrm{Mg}$ is required for full function of the adenylate cyclase complex. Hypomagnesemia reduces ability of parathyroid hormone stimulated cells to produce cyclic AMP, resulting in failure to activate the target cell (Goff, 2008; Degaris \& Lean, 2009). In most cases, hypomagnesemia does not present clinically, but attacks dairy cows both sub-clinically and chronically, especially after delivery (Mulligan \& Doherty, 2008; Pham et al., 2014). The prevalence of subclinical hypomagnesemia has not been adequately quantified in dairy herds, despite being an important risk factor for hypocalcemia usually associated with the development of peripartum metabolic disorders (Schimitt et al., 2016).

The aim of this study was to determine the localised prevalence of subclinical hypomagnesemia in pre- and postpartum dairy cows inserted in milkproduction systems in the Sousa microregion and the district of São João do Rio do Peixe, both in the State of Paraíba, Brazil.

\section{MATERIALS AND METHODS}

The protocols of this research were approved by the Ethics Commission for Animal Use (CEUA) of the Federal
Institute of Education, Science and Technology Paraíba, under Protocol No. 23000.000749.2017-17.

The research was carried out in the Sousa microregion, Paraíba state, located at $06^{\circ} 50^{\prime} 22^{\prime \prime} \mathrm{S}, 38^{\circ} 17^{\prime} 42^{\prime \prime} \mathrm{W}$, at an altitude of 220 metres, in an area of 4.784,729 $\mathrm{km}^{2}$ and in the district of São João do Rio do Peixe, Cajazeiras microregion, Paraíba state, located at $6^{\circ} 43^{\prime} 52^{\prime \prime} \mathrm{S}$, $38^{\circ} 26^{\prime} 53^{\prime \prime} \mathrm{W}$, at an altitude of 243 metres, in an area of $474,43 \mathrm{~km}^{2}$. The predominant climate in the region is hot semiarid, type Bsh, according KöpperGeiger (Pell et al., 2007), with a mean annual rainfall of $1050,2 \mathrm{~mm}$, concentrated from January to June. The mean annual temperature is $26.6{ }^{\circ} \mathrm{C}$, with a minimum and maximum respectively 21,2 and $33,1{ }^{\circ} \mathrm{C}$; the mean relative humidity is $63,7 \%$ (INMET, 2010).

The localised prevalence of subclinical hypomagnesemia was evaluated from May to October of 2017, corresponding to the rainy season, for the transition period (pre- and post-partum) of dairy cows inserted in 34 milk-production systems. The milk production systems that participated in the research had a low technological level, with manual milking, without using grains and mineral supplementation with $\mathrm{NaCl}$; medium technological level, with mechanical milking, use of grains at some stage of production, associated with the non-continuous use of mineral supplementation; and high technological level, with mechanical milking, continuous use of grains, silages, and commercial mineral supplement. The animals were Holstein and crossbreed Holstein, having as a food base with Brachiaria spp. or Panicum sp. roughage, in a rotational grazing system. 
The average daily production/cow in the properties participating in the research was $10.33 \pm 4.07$ L.day $^{-1}$, with a total daily production of 150,185 and 517 L.day $^{-1}$ for low, medium and high technological milk production systems, respectively.

Identification and selection of the properties were carried out through partnerships with the Technical Assistance and Rural Extension Company of Paraíba, Brazil which provided a database with the address and basic information of all the properties inserted in both districts. A minimum production of $150 \mathrm{~L}$ of milk per day was necessary for a property to be selected. To select the animals, the criteria were first-calf heifers and cows, irrespective of the number of lactations, that were within a period of four weeks before and four weeks after calving, with no symptoms of clinical hypomagnesemia or other infectious diseases.

After adopting the above criteria, visits were made to the selected properties, where, with the aid of a questionnaire, information was collected about nutritional management related to the form and type of feed and mineral supplement that were offered to the animals, in addition to the productive aspects (mean production of milk/day) and the breeding system.

Among the types of mineral supplements, the following were identified: a single supplement of $\mathrm{NaCl}$ (offered ad libitum); a supplement of $\mathrm{NaCl}+$ mineral base (Nutribac Champion $\left.{ }^{\circledR}\right)$ in the following concentrations: Ca 169 g. $\mathrm{kg}^{-1}$, P 125 g.kg-1, Mg 20 g.kg- ${ }^{-1}, \mathrm{~S} 11.8$ g. $\mathrm{kg}^{-1}$, Co 20000 mg.kg-1 , Fe 40000 mg.kg ${ }^{-1}$, I 21000 mg.kg ${ }^{-1}$, Mn 25000 mg.kg ${ }^{-1}$, Se $45000 \mathrm{mg} \cdot \mathrm{kg}^{-1}$, Zn $3300 \mathrm{mg} \cdot \mathrm{kg}^{-1}$ and $\mathrm{F}$ $1300 \mathrm{mg} \cdot \mathrm{kg}^{-1}$, diluted as per the manufacturer's recommendation of $1 \mathrm{~kg}$ of mineral base to $25 \mathrm{~kg}$ of NaCl ( $\mathrm{Na} 370$ g.kg-1; and $\mathrm{Cl} 626$ g. $\left.\mathrm{kg}^{-1}\right)$, with an estimated anion-cation balance $(\mathrm{mEq}$ 100 per gram of mineral mixture) of 93.42, based on the $\mathrm{Na}, \mathrm{Cl}$, and $\mathrm{S}$; and a commercial supplement (Novo Bovigold Tortuga $\left.{ }^{\circledR}\right)$ in the following concentrations: Ca 190-220 g.kg-1, P 60 g.kg-1, S 20 g. $\mathrm{kg}^{-1}, \mathrm{Mg} 20$ g. $\mathrm{kg}^{-1}$, K 35 g.kg ${ }^{-1}, \mathrm{Na} 70$ g.kg ${ }^{-1}, \mathrm{Cl} 119$ g.kg ${ }^{-1}$, Co 15 mg.kg-1, Cu 700 mg.kg ${ }^{-1}$, Cr 10 mg.kg ${ }^{-1}$, Fe 700 mg.kg- ${ }^{-1}$, I 40 mg. $\mathrm{kg}^{-1}$, Mn 1600 mg.kg ${ }^{-1}$, Se 19 mg.kg- ${ }^{-1}$, Zn 2500 mg.kg${ }^{1}$ and F $600 \mathrm{mg} \cdot \mathrm{kg}^{-1}$, with an estimated anion-cation balance of +183.88 , based on the $\mathrm{Na}, \mathrm{K}, \mathrm{Cl}$ and $\mathrm{S}$.

A supplement of $\mathrm{NaCl}+$ mineral-base mixture and a commercial supplement were offered to the cows following the manufacturer's recommendations of 100 g. day ${ }^{-1}$ and 20 to $30 \mathrm{~g}$ per $100 \mathrm{~kg}$ of body weight.day ${ }^{-1}$ respectively.

A total of 357 blood samples, 106 from pre-partum lactating cows and 251 from lactating cows in the post-partum period, were collected by venepuncture, using a $25 \times 0.8 \mathrm{~mm}$ needle for vacuum blood collection and a $10 \mathrm{~mL}$ Vacutainer ${ }^{\circledR}$ tube with clot activator. After collection, the samples were refrigerated in a cool box and sent to the Clinical Analysis Laboratory of the Federal Institute of Education, Science and Technology Paraíba.

The tubes were centrifuged at $3.600 \mathrm{rpm}$ for 10 minutes and the serum removed to determine the magnesium concentration using a LabTest Magnesium biochemical kit (Magnesium - Ref. 50, Labtest Diagnóstica, ANVISA10009010012, LabTest Diagnostica S.A., CNPJ 16,516,296/0001-38, Lagoa Santa, Minas Gerais).

The analyses were carried out by colorimetry, using a BIO-2000 IL semi- 
automatic biochemical analyser (Bioplus, Produtos para Laboratórios Ltda, Barueri, São Paulo), available from the Clinical Analysis Laboratory of the IFPB Veterinary Hospital, Sousa Campus.

Subclinical hypomagnesemia was diagnosed in first-calf heifers and cows showing serum $\mathrm{Mg}$ levels of less than 1.8 mg.dL ${ }^{-1}, \quad\left(0.8\right.$ mmol. $\left.\mathrm{L}^{-1}\right)$ and which presented no clinical symptoms, as recommended by Goff (2008).

The data were analysed with the PROC MEANS procedure of the SAS (2001) statistical software, using descriptive statistics for the mean, standard deviation and coefficient of variation. A further test of data adherence to normality was carried out using the PROC UNIVARIATE procedure, with discrimination by the Shapiro-Wilk test at a significance level of .05. After verifying normal data distribution, the mean values were compared by Duncan's test at a significance level of .05 . The effects of the adopted type of supplement were evaluated: a single supplement of $\mathrm{NaCl}$, a supplement of $\mathrm{NaCl}+$ mineral base and a commercial supplement. The reproductive status of the pre- and post-partum cows on the occurrence of subclinical hypomagnesemia was also evaluated.

\section{RESULTS}

Subclinical hypomagnesemia total prevalence

A total mean prevalence, including preand post-partum period and type of mineral supplement, for subclinical hypomagnesemia of $9.52 \%$ was found, where the first-calf heifers and multipliers cows presented a serum $\mathrm{Mg}$ level below the lower limit of $1.8 \mathrm{mg}$.dL1 established for the species. This value is considered high, since it represents the average of 357 samples collected and the fact that most properties provide commercial supplement.

In evaluating serum $\mathrm{Mg}$ levels as a function of the type of mineral supplement offered to the herds, including pre- and post-partum, it was seen that heifers and dairy cows receiving commercial mineral supplement displayed a higher percentage of subclinical hypomagnesemia, with $10.53 \%$ (34) of the cows below the lower limit. Dairy cows receiving single supplement of $\mathrm{NaCl}$ and supplement of $\mathrm{NaCl}+$ mineral base did not show serum $\mathrm{Mg}$ levels below $1.8 \mathrm{mg} \cdot \mathrm{dL}^{-1}$, however $23.08 \%$ (3) and $14.29 \%$ (3) animals were in a borderline situation, respectively (Table 1). 
Table 1. Localised prevalence and absolute value of serum $\mathrm{Mg}$ levels $\left(\mathrm{mg}_{\mathrm{dL}} \mathrm{dL}^{-1}\right)$ for type of mineral supplement in 357 lactating cows (including pre- and post-partum), in the Sousa microregion, PB, Brazil

\begin{tabular}{|c|c|c|c|c|}
\hline & \multicolumn{3}{|c|}{ Type of mineral supplement } \\
\hline & & $\begin{array}{l}\text { Single supplement } \\
\text { of } \mathrm{NaCl}\end{array}$ & $\begin{array}{l}\text { Supplement of } \mathrm{NaCl}+ \\
\text { mineral base }\end{array}$ & $\begin{array}{l}\text { Commercial } \\
\text { supplement }\end{array}$ \\
\hline Serum interva & & Serum $\mathrm{Mg}$ & & \\
\hline $\begin{array}{l}\text { Above } \\
\text { mg.dL }\end{array}$ & 2.4 & $76.92 \%(10)$ & $85.71 \%(18)$ & $52.01 \%(168)$ \\
\hline $\begin{array}{l}\text { From } 1.8 \text { to } \\
\text { mg.dL }^{-1}\end{array}$ & 2.4 & $23.08 \%(3)$ & $14.29 \%(3)$ & $37.46 \%(121)$ \\
\hline $\begin{array}{l}\text { Below } \\
\text { mg.dL }\end{array}$ & 1.8 & $0.00 \%(0)$ & $0.00 \%(0)$ & $10.53 \%(34)$ \\
\hline
\end{tabular}

${ }^{\text {a} A c c o r d i n g ~ t o ~ G o f f ~(2008) . ~}$

Effect reproductive period and type of mineral supplement on serum $\mathrm{Mg}$ levels In relation to the reproductive period of the first-calf heifers and lactating cows, it was found that serum $\mathrm{Mg}$ levels were lower post-partum, with a percentage of $9.96 \%$ (25) relative to the pre-partum period, which showed a prevalence of hypomagnesemia of $8.49 \%$ (9) (Table 2).

Table 2. Localised prevalence and absolute value of serum $\mathrm{Mg}$ levels (mg.dL $\mathrm{dL}^{-1}$ ) for reproductive period in 357 lactating cows, in the Sousa microregion, PB, Brazil

\begin{tabular}{lll}
\hline & \multicolumn{2}{l}{ Reproductive period } \\
\cline { 2 - 3 } & Pre-partum & Post-partum \\
\hline Serum interval $^{\text {a }}$ & Serum $\mathrm{Mg}$ & \\
\hline Above $2.4 \mathrm{mg} . \mathrm{dL}^{-1}$ & $56.60 \%(60)$ & $54.18 \%(136)$ \\
From 1.8 to $2.4 \mathrm{mg}^{-} \mathrm{dL}^{-1}$ & $34.91 \%(37)$ & $35.86 \%(90)$ \\
Below $1.8 \mathrm{mg} . \mathrm{dL}^{-1}$ & $8.49 \%(9)$ & $9.96 \%(25)$ \\
\hline
\end{tabular}

${ }^{\mathrm{a}}$ According to Goff (2008).

The type of mineral supplement influenced $(\mathrm{P}<.05)$ the serum $\mathrm{Mg}$ levels of the first-calf heifers and cows participating in the research. The supplement of $\mathrm{NaCl}+$ mineral base resulted in an increase in serum $\mathrm{Mg}$ levels; however, the commercial supplement presented reduced values for $\mathrm{Mg}$ concentration, being similar to the single supplement $\mathrm{NaCl}$ (Figure 1). 
Figure 1. Mean values and standard deviation of serum $\mathrm{Mg}$ levels $\left(\mathrm{mg} \cdot \mathrm{dL}^{-1}\right)$ for type of mineral supplement in 357 lactating cows, in the Sousa microregion, PB, Brazil. *Mean values followed by similar letters do not differ by Duncan's test $(\mathrm{P}>.05)$

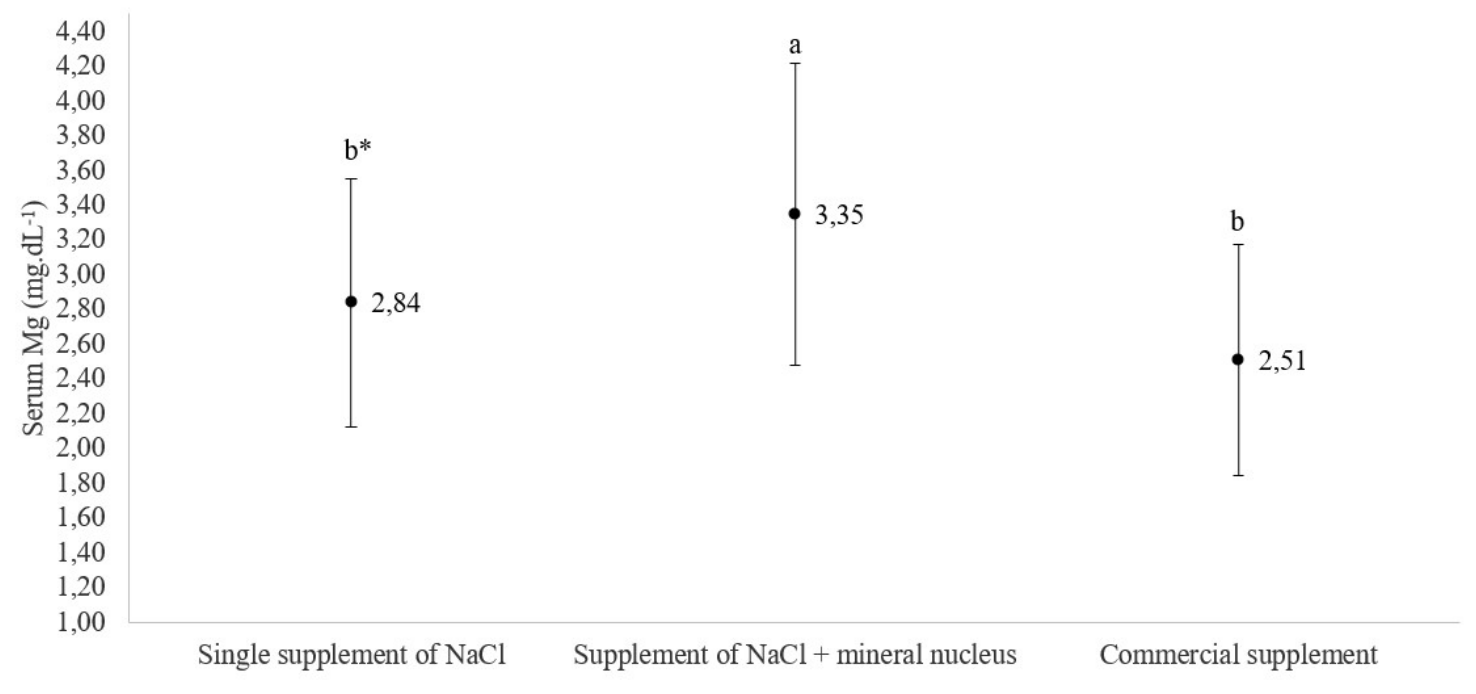

Despite the number of cows showing a decrease in $\mathrm{Mg}$ concentration being greater during the post-partum period, in this study, there was no significant difference $(\mathrm{P}<.05)$ in serum $\mathrm{Mg}$ concentrations in relation to the reproductive period of the cows. There was a tendency to decrease the mean serum $\mathrm{Mg}$ levels of by $0.11 \mathrm{mg} . \mathrm{dL}^{-1}$ for the post-partum period, as a result of the physiological events that occur. In both periods the serum $\mathrm{Mg}$ levels are within the suggested range for the species, from 1.8 to $2.4 \mathrm{mg} . \mathrm{dL}^{-1}$ (Figure 2 ).

Figure 2. Mean values and standard deviation of serum $\mathrm{Mg}$ levels (mg.dL $\mathrm{dL}^{-1}$ ) for reproductive status in 357 lactating cows, in the Sousa microregion, PB, Brazil. * Mean values followed by similar letters do not differ by Duncan's test (P > $.05)$
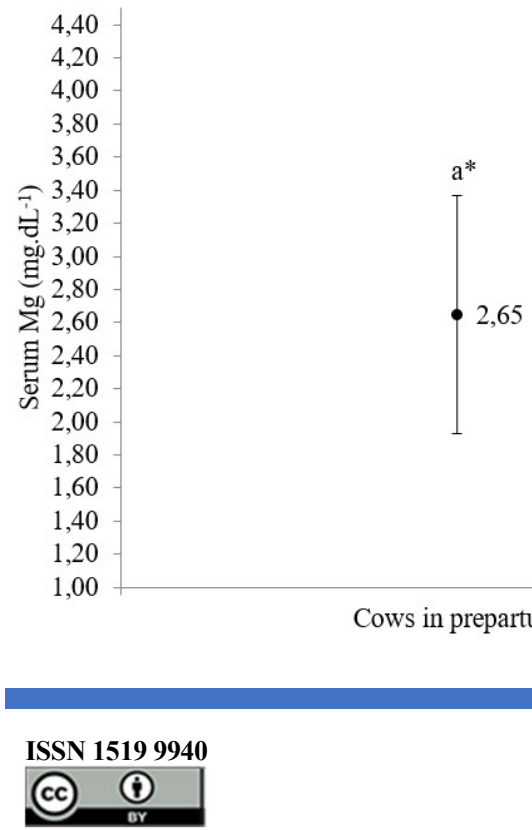


\section{DISCUSSION}

In the Northeast region of Brazil, the mineral supplementation of dairy cattle occurs basically in an ad libitum form, in separate feeders, where the animals consume the mineral supplement according to their needs. In the form of forced intake, in which macros and micro mineral elements are added to the total diet. A common mistake in this region is the isolated supplementation with $\mathrm{NaCl}$, as it is considered cheap and accessible.

The mean prevalence found in this research is similar to results found by Masoero et al. (2003), in which $12 \%$ of cows had serum Mg levels below the recommended levels, but higher than those found by Neves et al. (2017) and Fiorentin et al. (2018), where $4 \%$ and $7.4 \%$ of the animals respectively were classified as having the disorder.

Although commercial mineral supplement is considered the most appropriate choice of meeting the mineral demands of the animals, when not correctly supplied, it can cause an imbalance in blood mineral levels, and lead to disorders in the animal's metabolism. During visits to the properties participating in the research, it was found that many producers chose to purchase commercial supplement, as they felt that the commercial product offered greater reliability with regard to the nutritional levels necessary for maintaining the health of the animal.

Among the limiting factors for the occurrence of hypomagnesemia in cows that received commercial supplement, the following can be included: the improper dilution of commercial mineral mix with common salt $(\mathrm{NaCl})$ in order to increase the yield of the "mineral salt"; supplements of dubious origin, which cannot be relied on to meet necessary requirements, a common situation with mineral bases; combinations of minerals that may be antagonistic to other minerals; and offering smaller quantities than necessary and using troughs of limited size. According Malafaia et al. (2014) errors in the management of mineral supplement can be found in various properties that carry out livestock activities, and happen due to misunderstandings and ideas which the producers have learned from past generations or from colleagues; these generate some confusion and are the cause of considerable economic loss to the sector.

The cows that received the single supplement of $\mathrm{NaCl}$, or with the addition of a mineral base, showed no signs of the disorder, possibly because this research was carried out during the rainy season, when the nutritional value of the pastures was higher, contributing to maintain $\mathrm{Mg}$ levels within the normal range. The average daily production/cow, $7.5 \pm 1$ L.dia ${ }^{-1}$, and total daily production of 150 L.dia ${ }^{-1}$ should also be considered, which makes cows have less $\mathrm{Mg}$ for milk synthesis.

Pechin et al. (2011) evaluated the levels of $\mathrm{Mg}$ in the blood of dairy cows and the amount available in the pasture over the four seasons of the year. The authors found that the cows had lower values for serum $\mathrm{Mg}\left(1.44 \pm 0.18 \mathrm{mg} . \mathrm{dL}^{-1}\right)$ during the winter season, which coincides with the driest period, showing that the seasons differ significantly from each other $(\mathrm{P}<.05)$. These results are corroborated by Moreira et al. (2015), who obtained higher concentrations of serum $\mathrm{Mg}$ during the summer (2.88 $\left.\mathrm{mg} \cdot \mathrm{dL}^{-1}\right)$, a season with more rainfall. 
The reduction in peripartum serum $\mathrm{Mg}$ levels is due to this and other minerals being required for the development of the calf and to produce colostrum and milk, which together with a low drymatter intake (DMI), leads to insufficient nutrient uptake (Martens et al., 2018; Doncel et al., 2019). According to Martín-Tereso \& Martens (2014), Mg absorption should exceed the requirement of this mineral for the milk, endogenous secretion and tissue absorption (soft tissue and bones).

In a study carried out by Alvarenga et al. (2015), of the 12 animals evaluated, one presented subclinical hypomagnesemia (1.67 mg.dL ${ }^{-1}$ ) five days after calving. Schimitt et al. (2016), evaluating 11 cows during the transitional period, found that five presented subclinical hypomagnesemia (blood levels below $1.8 \mathrm{mg} . \mathrm{dL}^{-1}$ ) in both pre- and postpartum episodes, with emphasis on two cows whose $\mathrm{Mg}$ concentrations remained below normal serum levels for $60 \%$ of the experimental period.

For the peripartum cow, the status of the $\mathrm{Mg}$ interferes with $\mathrm{Ca}$ metabolism. Hypomagnesemia is a well-known risk factor for hypocalcemia (Neves et al., 2017). This is due to $\mathrm{Mg}$ acting as a binding cofactor between parathormone and its receptor, with its presence necessary for the parathyroid hormone (PTH) response to occur and for maintaining calcium homeostasis (Goff, 2008).

In addition, when analysing the types of feed management used on the properties, it was found that as the cows entered the post-partum period, the producers reduced the supply of bulk to increase the concentrate and milk production. However, this may be more expensive and cause the animals to develop hypomagnesemia, exactly at the most critical period of greater nutrient demand. According to Zelal (2017), Mg is required for all animals, but is more critical for ruminants.

At this time, factors such as nutrition, management and the environment of the cows, become determinants for the prevention of such disorders as hypomagnesemia and hypocalcemia, with minerals such as $\mathrm{Mg}$ and $\mathrm{K}$ being more dependent on environmental features, including feeding and management conditions and the $\mathrm{Ca}$ of the individual (Tsiamadis et al., 2016; Manuelian et al., 2018). According to Lean et al. (2006), an increase in $\mathrm{Mg}$ concentration of 3 to $4 \mathrm{~g} \cdot \mathrm{kg}^{-1}$ dry matter in the animals' diet can reduce the risk of hypocalcemia in the herds by approximately $62 \%$.

Of the cows evaluated by Schimitt et al. (2016), 41\% presented subclinical hypomagnesemia, with the animals under continuous grazing of Brachiaria Decumbens and receiving commercial mineral supplement at will. The data is similar to that found in this study, where the group of cows that received commercial mineral supplement had the lowest levels of $\mathrm{Mg}$ in the blood.

It should be noted that the heifers and dairy cows that were supplemented with the commercial mineral mixture presented subclinical hypomagnesemia (Figure 1) an unexpected situation due to the quality of the formulation offered. However, when evaluating the production data, it was verified that these animals were inserted in high technological systems of producers with greater purchasing power who therefore had in their herds genetically superior animals of greater dairy production, with an average daily production/cow of $15 \pm$ 3 L.day $^{-1}$, demanding greater amounts of $\mathrm{Mg}$ for milk biosynthesis, compared to 
the cows inserted in low technological level systems, $7.5 \pm 1$ L. day $^{-1} /$ cow, where the producers supplied single supplement of $\mathrm{NaCl}$.

High-production animals have greater nutritional requirements, and consequently require a balanced and continuous mineral supplement, since problems with these basics can compromise mineral serum levels in the animal's organism. This is confirmed by Cupertino et al. (2011), who found a decrease in $\mathrm{Mg}$ concentrations, both when the mineral supplement was no longer offered to the cows and when the animals were in a period of greater milk production.

As such, it is necessary to emphasise the importance of the current production scenario on the correct management of mineral supplement. For this, the producer should consider the most suitable type of supplement for each reproductive stage of the animals, the amount to be offered as necessary, and the availability of good facilities to meet the demand for supplement consumption by the cows.

In this study, the reproductive period of cows has no influence on serum magnesium levels (Figure 2). These results can be compared to those of Cupertino et al. (2011), who evaluated $\mathrm{Mg}$ concentrations during the transition period ( 30 days before and 30 days after calving) and found there to be no significant difference, both in relation to the period of the cows or in relation to the season.

The prevention of subclinical hypomagnesemia should be directed at two main objectives: the continuous supply of adequate levels of $\mathrm{Mg}$ in the diet and maximising the absorption of this essential mineral, with salt supplements being the most common choice due to the cost and taste (Odette, 2005). In most cases, the producer does not feel the negative impact of peripartum disorders until they become an obvious problem, such as clinical cases. However, under the current conditions that target high milk production, $\mathrm{Mg}$ deficiency may be responsible for considerable economic loss (Moreira et al., 2015).

Subclinical hypomagnesemia was a disorder found in dairy cows of the Sousa microregion and the district of São João do Rio do Peixe, in the State of Paraíba, occurring with a localised prevalence of $9.52 \%$. The prevalence for pre- and post-partum cows was $8.49 \%$ and $9.96 \%$ respectively. There was no significant difference in prevalence in relation to the reproductive period of the cows. Despite commercial supplement being the most used, it was not sufficient to meet magnesium requirements due to errors in supply management.

\section{ACKNOWLEDGMENTS}

The authors would like to thank the PróReitoria de Pesquisa, Inovação e PósGraduação (PRPIPG) of Instituto Federal de Educação, Ciência e Tecnologia da Paraiba, Chamada Interconecta - No. 01/2017, for the financial support (bench fee and scientific initiation grant) that made this research possible. To Technical Assistance and Rural Extension Company of Paraiba and the Isis Dairy Company in the city of Sousa, Paraiba, Brazil for the support.

\section{REFERENCES}

ALVARENGA, E.A.; MOREIRA, G.H.F.A.; FACURY, E.J.F.; LEME, 
F.O.P.; COELHO, S.G.; MOLINA, L.R.; LIMA, J.A.M.; CARVALHO, A.U. Avaliação do perfil metabólico de vacas da raça Holandesa durante o período de transição. Pesquisa Veterinária Brasileira, v.35, n.3, p.281- 290, 2015.

CUPERTINO, C.F.; NETO, E.P.; BARCELLOS, M.P.; SENA, F.P.; LENZ, D.; BARIONI, G. Avaliação do perfil metabólico em vacas leiteiras de alta produção no período de transição.

Publicações em Medicina Veterinária e Zootecnia, v.5, n.18, p.1112-1117, 2011.

DEGARIS, P.J.; LEAN, I.J. Milk fever in dairy cows: A review of pathophysiology and control principles. Veterinary Journal, v. 176, n.1, p.5869, 2009.

DONCEL, B.; CAPELESSO, A.; GINANNITTI, F.; CAJARVILLE, C. MACÍAS-RIOSECO, M.; SILVEIRA, C.; COSTA, R.A.; RIET-CORREA, F. Hypomagnesemia in dairy cattle in Uruguay. Pesquisa Veterinária

Brasileira, v.39, n.8, p.564-572 2019.

FIORENTIN, E.L.; ZANOVELLO, S.; GATO, A.; PIOVEZAN, A.L.; ALVES, M.V.; ROCHA, R.X.; GONZALEZ, F. Occurrence of subclinical metabolic disorders in dairy cows from western Santa Catarina state, Brazil. Pesquisa Veterinária Brasileira, v.38, n.4, p.629- 634, 2018.

GOFF, J.P. The monitoring, prevetion, and treatment of milk fever and subclinical hypocalcemia in dairy cows. Veterinary Journal, v.176, n.1, p.5057, 2008.
GOFF, J.P. Calcium and Magnesium Disorders. Veterinary Clinics of North America: Food Animal Practice, v.30, n.2, p.359-381, 2014.

Instituto Nacional de Meteorologia

(INMET), 2010. Normais

\section{climatológicas.}

http://www.inmet.gov.br/portal/index.p $\mathrm{hp} ? \mathrm{r}=\mathrm{clima} /$ normaisClimatologicas (accessed 15 July 2018).

LEAN, I.J.; DEGARIS, P.J.; MCNEIL, D.M.; BLOCK , E. Hypocalcemia in dairy cows: Meta- analysis and dietary cation anion difference theory revisited. Journal of Dairy Science, v.89, n.2, p. 669- 684, 2006.

MALAFAIA, P.; COSTA, R.M.; BRITO, M.F.; PEIXOTO, P.V.; BARBOSA, J.D.; TOKARNIA, C.H.; DOBEREINER J. 2014. Equívocos arraigados no meio pecuário sobre deficiências e suplementação minerais em bovinos no Brasil. Pesquisa Veterinária Brasileira, v.34, n.3, p.244- 249, 2014.

MANUELIAN, C.L.; PENASA, M.; VISENTIN, G.; ZIDI, A.; CASSANDRO, M.; MARCHI, M. Mineral composition of cow milk from multibreed herds. Animal Science Jounal, v.89, n.11, p.1622-1627, 2018.

MARTENS, H.; LEONHARDMAREK, S.; RONTGEN, M.; STUMPFF, F. Magnesium homeostasis in cattle: absorption and excretion.

Nutrition Research Reviews, v.31, n.1, p.114-130, 2018.

MARTÍN-TERESO, J.; MARTENS, H. Calcium and magnesium physiology and nutrition in relation to the prevention of milk fever and tetany 
(Dietary management of macrominerals in preventing disease). Veterinary

Clinics of North America: Food Animal Practice, v.30, n.3, p.643-670, 2014.

MASOERO, F.; MOSCHINI, M.; PULIMENO, A.M. Serum calcium and magnesium level in dairy cows at calving. Italian Journal of Animal Science, v.2, n.1, p.172-174, 2003.

MOREIRA, T.F.; ZAMBRANO, J.U.; PAULA, V.M.; CASAGRANDE, F.P.; FILHO, E.J.F.; MOLINA, L.R.; LEME, F.O.P.; CARVALHO, A.U. Perfil mineral de vacas mestiças Girolanda no período de transição em sistema semiintensivo em duas estações do ano.

Pesquisa Veterinária Brasileira, v.35, n.3, p. 249-257, 2015.

MULLIGAN, F.J.; DOHERTY, M.L. Production diseases of the transition cow. Veterinary Journal, v.176, n.1, p.3-9, 2008.

NEVES, R.C.; LENO, B.M.; STOKOL, T.; OVERTON, T.R.; MCART, J.AA. Risk factors associated with postpartum subclinical hypocalcemia in dairy cows. Journal of Dairy Science, v.100, n.5, p. 3796-3804, 2017.

ODETTE, O. Grass tetany in a herd of beef cows. Canadian Veterinary Journal, v. 46, n.8, p. 732- 734, 2005.

PEEL, M.C.; FINLAYSON, B.L.; MCMAHON, T.A. Updated world map of the Köppen-Geiger climate classification. Hydrology and Earth System Sciences, v.11, n.5, p.16331644, 2007.
SAS Inc., 2001. SAS ${ }^{\circledR}$ User's Guide: Statistics, Version 8.2 Edition. SAS Inc., Cary, NC, USA.

SCHIMITT, E.; PEREIRA, R.A.; HOFFMANN, D.A.C.; VENDRAMIN, L.; LIMA, M.E.; FAROFA, T.S.; LOPES, M.S.; MONTAGNER, P.; CÔRREA, M.N.; PINO, F.A.B. Hipomagnesemia subclínica em vacas leiteiras durante o período de transição: ocorrências hormonais e metabólicas.

Revista Brasileira de Ciência

Veterinária, v. 23, n.1, p. 66-70, 2016.

SHEEHY, M.R.; FAHEY, A.G.; AUNGIER, S.P.M.; CARTER, F.; CROWE, M.A.; MULLIGAN, F.J. A comparison of serum metabolic and production profiles of dairy cows that maintained or lost body condition 15 days before calving. Journal of Dairy Science, v.100, p.536-547, 2016.

PHAM, P.C.T., PHAM, P.A.T., PHAM, S.V., PHAM, P.T.T., PHAM, P.M.T.; PHAM, P.T.T. Hypomagnesemia: a clinical perspective. International Journal of Nephrology and Renovascular Disease, v.7, p.219-230, 2014.

PECHIN, G.H.; CSEH, S.; KENNY, O. Hipomagnesemia en vacas de cría en un campo de la zona del caldenal. Ciencia Veterinaria, v.13, n.1, p.70-75, 2016.

TSIAMADIS, V.; BANOS, G.; PANOUSIS, N.; KRITSEPIKONSTANTINOU, M.; ARSENOS, G.; VALERGAKIS, G.E. Genetic parameters of subclinical macromineral disorders and major clinical diseases in postparturient Holstein cows. Jounal of Dairy Science, v.99, n.11, p.8901-8914, 2016. 
WANG, X.; LI, X.; ZHAO, C.; HU, P.; CHEN, H.; LIU, Z.; LIU, G.; WANG, Z. Correlation between Composition of the Bacterial Community and Concentration of Volatile Fatty Acids in the Rumen during the Transition Period and Ketosis in Dairy Cows. Applied and Environmental Microbiology, v.78, n.7, p.2386-2392, 2012.

ZELAL. A. Hypomagnesemia tetany in cattle. Journal of Advances in Dairy Research, v.5, n.2, p.1-9, 2017. 